\title{
INCIDENCE OF COMMON INFECTIONS OF CHILDHOOD BY
}

\author{
B. BENJAMIN and A. T. GORE \\ From the Public Health Department, London County Council
}

In this study of the incidence of infectious disease in childhood, reference has been made to three main sources of information on morbidity:

(1) notifications made to the local sanitary authority by medical practitioners where such diseases are notifiable.

(2) pre-admission histories obtained from patients admitted to L.C.C.* fever hospitals in 1938. $†$

(3) reports from L.C.C. schools of causes of absence of pupils.

All three sources are limited, the first as to scope of diseases, the second as to time, and the third as to age coverage and degree of completeness in reporting (especially during the war years, 1939-45, which have been ignored). Mortality is referred to where the figures are of interest. The diseases studied are dealt with in the following order: chicken-pox, diphtheria, german measles (rubella), measles, mumps, whooping cough, scarlet fever.

ChICKen-Pox.-A sample of hospital admissions in 1938 gave the figures in Table $I$ for patients admitted with diseases other than chicken-pox.

TABLE I

INCIDENCE OF CHICKEN-POX IN HOSPITAL ADMISSIONS, BY SEX, 1938.

\begin{tabular}{|c|c|c|c|c|c|c|c|c|}
\hline \multirow{3}{*}{ Age } & \multicolumn{4}{|c|}{ Male } & \multicolumn{4}{|c|}{ Female } \\
\hline & \multirow{2}{*}{$\begin{array}{l}\text { Total } \\
\text { Hos- } \\
\text { pital } \\
\text { Ad- } \\
\text { mis- } \\
\text { sions }\end{array}$} & \multicolumn{3}{|c|}{$\begin{array}{l}\text { Patients with History } \\
\text { of Chicken-pox }\end{array}$} & \multirow{2}{*}{$\begin{array}{c}\text { Total } \\
\text { Hos- } \\
\text { pital } \\
\text { Ad- } \\
\text { mis- } \\
\text { sions }\end{array}$} & \multicolumn{3}{|c|}{$\begin{array}{c}\text { Patients with History } \\
\text { of Chicken-pox }\end{array}$} \\
\hline & & No. & $\begin{array}{l}\text { Per } \\
\text { cent. }\end{array}$ & $\begin{array}{c}\text { Gradu- } \\
\text { ated Per- } \\
\text { centage } \\
\ddagger\end{array}$ & & No. & $\begin{array}{l}\text { Per } \\
\text { cent. }\end{array}$ & $\begin{array}{c}\text { Gradu- } \\
\text { ated Per- } \\
\text { centage } \\
\ddagger\end{array}$ \\
\hline $\begin{array}{l}0- \\
1- \\
2- \\
3- \\
4- \\
5- \\
6- \\
7- \\
8- \\
9- \\
10-14 \\
15\end{array}$ & $\begin{array}{r}358 \\
406 \\
358 \\
253 \\
198 \\
145 \\
137 \\
90 \\
60 \\
55 \\
172 \\
-\end{array}$ & $\begin{array}{r}2 \\
16 \\
30 \\
32 \\
36 \\
30 \\
43 \\
30 \\
23 \\
27 \\
72 \\
-\end{array}$ & $\begin{array}{r}0 \cdot 6 \\
3 \cdot 9 \\
8 \cdot 4 \\
12 \cdot 6 \\
18 \cdot 2 \\
20 \cdot 7 \\
31 \cdot 4 \\
33 \cdot 3 \\
38 \cdot 3 \\
49 \cdot 1 \\
41 \cdot 9 \\
-\end{array}$ & $\begin{array}{r}0 \cdot 3 \\
2 \cdot 4 \\
6 \cdot 3 \\
11 \cdot 6 \\
17 \cdot 6 \\
23 \cdot 7 \\
29 \cdot 4 \\
34 \cdot 3 \\
38 \cdot 3 \\
41 \cdot 3 \\
45 \cdot 8 \\
46 \cdot 9\end{array}$ & $\begin{array}{r}316 \\
366 \\
415 \\
253 \\
163 \\
177 \\
116 \\
79 \\
50 \\
57 \\
124 \\
-\end{array}$ & $\begin{array}{r}3 \\
13 \\
33 \\
42 \\
36 \\
39 \\
42 \\
21 \\
20 \\
23 \\
51 \\
-\end{array}$ & $\begin{array}{r}0 \cdot 9 \\
3 \cdot 6 \\
8 \cdot 0 \\
16 \cdot 0 \\
22 \cdot 6 \\
22 \cdot 1 \\
36 \cdot 0 \\
26 \cdot 2 \\
40 \cdot 6 \\
40 \cdot 0 \\
41 \cdot 1 \\
-\end{array}$ & $\begin{array}{r}0 \cdot 3 \\
2 \cdot 7 \\
7 \cdot 2 \\
12 \cdot 9 \\
19 \cdot 1 \\
25 \cdot 1 \\
30 \cdot 3 \\
34 \cdot 4 \\
37 \cdot 4 \\
39 \cdot 5 \\
42 \cdot 0 \\
42 \cdot 4\end{array}$ \\
\hline
\end{tabular}

$\ddagger$ Crude percentages were fitted to a curve of the form $y=a\left(1-e^{-c x^{2}}\right)$. Where $y=$ percentage, $x=$ age, and $a$ and $c$ are constants.

Table I indicates that about one-fifth of all

* London County Council. This body governs the inner ring of the London Urban Area, which is defined as the Administrative County of London, sometimes abbreviated as London A.C.

$t$ These histories have been tabulated and utilized on the assumption that the histories of disease $X$ in patients admitted for disease other than $X$ would be typical of the pre-war school population. children contract chicken-pox before the age of 5 , and a further quarter between the ages of 5 and 15.

The percentage curve is rising very slowly at 14 , and extrapolation suggests an asymptotic limit at a little below 50 per cent., so that about one-half of the population never has chicken-pox. The incidence seems to be a little lower at first in boys than in girls, but it is ultimately slightly higher.

Reported absences from what were formerly known as elementary schools in London for chickenpox from 1926-1938 were very stable from year to year and have therefore been averaged in groups of years (Table II).

TABLE II

L.C.C. SCHOOL ABSENCES FROM CHICKEN-POX, 1926-38.

\begin{tabular}{c|c|c}
\hline Period & Mean Annual Cases & $\begin{array}{c}\text { Annual Attack Rate per } \\
\text { cent. of School Roll }\end{array}$ \\
\hline $1926-30$ & 13,941 & $2 \cdot 23$ \\
$1931-35$ & 11,266 & $2 \cdot 02$ \\
$1936-38$ & 9,903 & $2 \cdot 16$ \\
\hline
\end{tabular}

This attack rate suggests a total incidence during school life of $10 \times 2.2$ ( 22 per cent.), which is consistent with the histories obtained from hospital patients. Thus the school reports appear to be reasonably complete. On the other hand, it has been claimed that, among entrants to English public boarding-schools in 1930-34 (School Epidemics Committee, Spec. Rep. Ser. med. Res. Coun., No. 227, 1938), 66.6 per cent. of boys and $57 \cdot 1$ per cent. of girls had suffered an attack (i.e. before the age of 10). These are much higher proportions than those shown by L.C.C. records. This is less likely to be due to under-reporting in L.C.C. schools, than to the fact that public-school children spend many of their earlier years at residential preparatory schools with a different exposure and immunity experience. It appears that the data used by the School Epidemics Committee are derived from a very select population.

Since 1945 the school reports have been as shown 
in Table III, which indicates that the pre-war attackstill rate applies.

TABLE III

L.C.C. SCHOOL ABSENCES FROM CHICKEN-POX, 1946-50.

\begin{tabular}{c|c|c}
\hline Year & Number & Per cent. of School Roll \\
\hline 1946 & 5,602 & $1 \cdot 67$ \\
1947 & 7,423 & $2 \cdot 11$ \\
1948 & 7,745 & $2 \cdot 08$ \\
1949 & 5,528 & $1 \cdot 46$ \\
1950 & 7,773 & $2 \cdot 04$ \\
\hline
\end{tabular}

Although death from chicken-pox is rare, the disease does occasionally appear on death certificates as the cause of death. Deaths in London Administrative County pre-war and post-war have been (total for quinquennia):

\begin{tabular}{c|c|c}
\hline \multirow{2}{*}{ Period } & \multicolumn{2}{|c}{ Age } \\
\cline { 2 - 3 } & $0-14$ & 15 and over \\
\hline $1935-39$ & 17 & -1 \\
\hline
\end{tabular}

There is a pronounced seasonal swing in incidence, which is minimal in September immediately after the summer holidays (50-60 cases a week in 1950), rises rapidly during October, and reaches a peak in December (350 cases weekly). Thereafter the figures decline slowly and irregularly as the effect of local outbreaks is felt.

DIPHTHERIA.- Notifications corrected for diagnosis have been available only since 1944 (Table IV). Since then the corrections factor has been fairly stable and this has been applied to the earlier uncorrected figures to obtain continuity (see Figure).

TABLE IV

NOTIFICATIONS OF DIPHTHERIA, LONDON A.C., 1931-50.

\begin{tabular}{c|c|c|c|c|c}
\hline \multicolumn{3}{c}{ Uncorrected } & & \multicolumn{2}{c}{ Corrected } \\
\cline { 1 - 2 } \cline { 5 - 6 } Year & Number & Year & Number & Year & Number \\
\hline 1931 & $\mathbf{8 , 3 8 4}$ & 1938 & $\mathbf{7 , 6 1 1}$ & 1944 & 758 \\
1932 & 8,087 & 1939 & 3,671 & 1945 & 801 \\
1933 & 9,557 & 1940 & 1,844 & 1946 & 747 \\
1934 & 11,782 & 1941 & 2,179 & 1947 & 451 \\
1935 & 9,294 & 1942 & 1,813 & 1948 & 335 \\
1936 & 7,030 & 1943 & 1,862 & 1949 & 221 \\
1937 & 7,810 & - & - & 1950 & 87 \\
\hline
\end{tabular}

The attack rate for ages $0-4$ has fallen from 6.04 per 1,000 in 1931 (estimated corrected) to 0.07 per 1,000 in 1950, and the rate for ages 5-14 has fallen from 3.58 in 1931 to 0.13 in 1950 .

Table V (opposite) shows that the incidence differs slightly in the two sexes.

In 1938, hospital records treated in the same way as for chicken-pox indicated that 6 per cent. of the population were attacked before the age of 5 , and a further 7 per cent. 10 between the ages of 5 and 15. On the other hand, the 1931 'corrected' notification rates quoted above would be consistent with percentages at corresponding age periods of 3.0 and 3.6 . If uncorrected notifications are used, the percentages become 5.0 and $6 \cdot 0$, and it appears therefore that, in giving medical histories, parents regarded admission to hospital for suspected diphtheria as sufficient evidence of contraction of the disease. Parents would remember the fact of hospital admission more clearly than any correction of diagnosis and the error of diagnosis was 26 per cent. (L.C.C. Annual Report, 1937). 
TABLE V

NOTIFICATIONS OF DIPHTHERIA, BY SEX, LONDON A.C., 1936-38 AND 1946-48.

\begin{tabular}{|c|c|c|c|c|c|}
\hline \multirow{2}{*}{ Period } & \multirow{2}{*}{ Age } & \multicolumn{2}{|l|}{ Male } & \multicolumn{2}{|l|}{ Female } \\
\hline & & Notifications & $\begin{array}{c}\text { Per 1,000 } \\
\text { living }\end{array}$ & Notifications & $\begin{array}{c}\text { Per 1,000 } \\
\text { living }\end{array}$ \\
\hline$\underset{*}{1936-38}$ & $\begin{array}{c}0- \\
1-2 \\
3-4 \\
5-9 \\
10-14 \\
15 \text { and } \\
\text { over }\end{array}$ & $\begin{array}{r}157 \\
890 \\
1,336 \\
2,605 \\
717 \\
591\end{array}$ & $\begin{array}{l}1 \cdot 92 \\
5 \cdot 88 \\
9 \cdot 32 \\
6 \cdot 15 \\
1 \cdot 73 \\
0 \cdot 13\end{array}$ & $\begin{array}{r}113 \\
675 \\
1,154 \\
2,783 \\
919 \\
1,509\end{array}$ & $\begin{array}{l}1 \cdot 41 \\
4 \cdot 55 \\
8 \cdot 10 \\
6 \cdot 68 \\
2 \cdot 24 \\
0 \cdot 28\end{array}$ \\
\hline $1946-48$ & $\begin{array}{l}0- \\
1-2 \\
3-4 \\
5-9 \\
10-14 \\
15 \text { and } \\
\text {.over }\end{array}$ & $\begin{array}{r}27 \\
132 \\
121 \\
244 \\
87 \\
143\end{array}$ & $\begin{array}{l}0 \cdot 27 \\
0 \cdot 72 \\
0 \cdot 93 \\
0 \cdot 87 \\
0 \cdot 33 \\
0 \cdot 04\end{array}$ & $\begin{array}{r}10 \\
86 \\
110 \\
194 \\
96 \\
283\end{array}$ & $\begin{array}{l}0 \cdot 10 \\
0 \cdot 49 \\
0 \cdot 88 \\
0 \cdot 71 \\
0 \cdot 37 \\
0.06\end{array}$ \\
\hline
\end{tabular}

* Crude notifications adjusted by estimated correction for error of diagnosis. In so far as the correction factor is based on total notifications, it may not be strictly correct to assume that this factor applies equally to individual age or sex groups. The comparison is in fact being made on crude notifications and the correction has only the effect of making the rates comparable with 1946-48 levels.

On the whole there is no reason to suspect undernotification of a disease in regard to which practitioners have been encouraged to err on the side of over-notification.

The school figures of Table VI, indicating an average annual rate of $0 \cdot 78$, would suggest that $10 \times 0.8$ (8 per cent.) contracted the disease between the ages of 5 and 15 , which agrees fairly closely with the figures derived from histories of hospital patients.

TABLE VI

L.C.C. SCHOOL ABSENCES FROM DIPHTHERIA, 1926-38.

\begin{tabular}{c|c|c}
\hline Period & Mean Annual Cases & $\begin{array}{c}\text { Annual Attack Rate per } \\
\text { cent. of School Roll }\end{array}$ \\
\cline { 1 - 2 } $1926-30$ & 5,257 & $\begin{array}{c}0.84 \\
1931-35\end{array}$ \\
$1936-38$ & 4,152 & 0.75 \\
0.500 & $0 \cdot 76$ \\
\hline
\end{tabular}

The School Epidemics Committee (1938) did not enquire into the past history of pupils with regard to this disease and no comparative figures can be given.

With regard to mortality, it is sufficient to record that in $\mathbf{1 9 5 0}$ there were only four deaths, all among infants who had not been previously immunized. With such reduced incidence as now obtains, any seasonal fluctuation in the incidence of diphtheria has largely disappeared and sporadic cases occur throughout the year at a fairly uniform rate.

German Measles (Rubella).-This disease is not notifiable in London A.C. It has only been separated from measles in the school reports since 1936.

Pre-war and post-war figures are compared in Table VII. There have occasionally been severe outbreaks, as in 1944 when 8,374 cases were reported from schools. Heavy outbreaks appear to have occurred also in 1933 and 1940 though no figures of incidence can be given.

L.C.C. SCHOOL ABSENCES FROM RUBELLA, 1936-38 AND 1946-50.

\begin{tabular}{c|c|c}
\hline Period & $\begin{array}{c}\text { Mean Annual Cases } \\
\text { Reported from Schools }\end{array}$ & $\begin{array}{c}\text { Annual Attack Rate per } \\
\text { cent. of School Roll }\end{array}$ \\
\hline $1936-38$ & 1,448 & $\begin{array}{l}0 \cdot 31 \\
1946-50\end{array}$ \\
\hline
\end{tabular}

Histories taken from L.C.C. hospital patients in 1939 are shown in Table VIII.

TABLE VIII

INCIDENCE OF RUBELLA IN HOSPITAL ADMISSIONS, BY SEX, 1938.

\begin{tabular}{|c|c|c|c|c|c|c|c|c|}
\hline \multirow{3}{*}{ Age } & \multicolumn{4}{|c|}{ Male } & \multicolumn{4}{|c|}{ Female } \\
\hline & \multirow{2}{*}{$\begin{array}{l}\text { Total } \\
\text { Hos- } \\
\text { pital } \\
\text { Ad- } \\
\text { mis- } \\
\text { sions }\end{array}$} & \multicolumn{3}{|c|}{$\begin{array}{l}\text { Patients with History } \\
\text { of Rubella }\end{array}$} & \multirow{2}{*}{$\begin{array}{l}\text { Total } \\
\text { Hos- } \\
\text { pital } \\
\text { Ad- } \\
\text { mis- } \\
\text { sions }\end{array}$} & \multicolumn{3}{|c|}{$\begin{array}{c}\text { Patients with History } \\
\text { of Rubella }\end{array}$} \\
\hline & & No. & $\begin{array}{l}\text { Per } \\
\text { cent. }\end{array}$ & $\begin{array}{c}\text { Gradu- } \\
\text { ated per- } \\
\text { centage }\end{array}$ & & No. & $\begin{array}{l}\text { Per } \\
\text { cent. }\end{array}$ & $\begin{array}{l}\text { Gradu- } \\
\text { ated per- } \\
\text { centage }\end{array}$ \\
\hline $\begin{array}{c}0- \\
1- \\
2- \\
3- \\
4- \\
5- \\
6- \\
7- \\
8- \\
9- \\
10-14 \\
15 \text { exact }\end{array}$ & $\begin{array}{r}392 \\
431 \\
408 \\
283 \\
226 \\
160 \\
151 \\
108 \\
84 \\
68 \\
175\end{array}$ & $\begin{array}{r}-8 \\
9 \\
9 \\
10 \\
4 \\
5 \\
8 \\
4 \\
4 \\
6\end{array}$ & $\begin{array}{l}-1 \cdot 9 \\
1 \cdot 9 \\
2 \cdot 2 \\
3 \cdot 2 \\
4 \cdot 4 \\
2 \cdot 5 \\
3 \cdot 3 \\
7 \cdot 4 \\
4 \cdot 8 \\
5 \cdot 9 \\
3 \cdot 4\end{array}$ & $\begin{array}{l}\overline{0.4} \\
0.9 \\
1.7 \\
2.6 \\
3.4 \\
4.2 \\
4.9 \\
5.4 \\
5.8 \\
6.4 \\
6.5\end{array}$ & $\begin{array}{r}315 \\
378 \\
442 \\
281 \\
185 \\
200 \\
132 \\
90 \\
58 \\
59 \\
132\end{array}$ & $\begin{array}{r}2 \\
7 \\
10 \\
8 \\
5 \\
7 \\
3 \\
1 \\
4 \\
3 \\
2\end{array}$ & $\begin{array}{l}0 \cdot 6 \\
1.9 \\
2 \cdot 3 \\
2.8 \\
2.7 \\
3 \cdot 5 \\
2 \cdot 3 \\
1.1 \\
6.9 \\
5 \cdot 1 \\
1.5\end{array}$ & $\begin{array}{l}\overline{0} \cdot 2 \\
0 \cdot 4 \\
0 \cdot 8 \\
1 \cdot 3 \\
1 \cdot 8 \\
2 \cdot 5 \\
3 \cdot 1 \\
3 \cdot 8 \\
4 \cdot 4 \\
6 \cdot 1 \\
7 \cdot 2\end{array}$ \\
\hline
\end{tabular}

The crude data were irregular and the fitted curves are not satisfactory even though the data at the ages of 10-14 have been ignored. The increase in those with histories between the ages of 5 and 15 of some 4 per cent. (both sexes combined) would suggest an annual attack rate in the school population of $(4 \div 10)$ per cent. which agrees fairly well with the observed rate of $0 \cdot 31$.

The School Epidemics Committee (1938), however, found that, of pupils (mostly over the age of 10) entering public boarding-schools, 28.6 per cent. of boys and 22.1 per cent. of girls had had attacks of german measles. These figures are much in excess of the corresponding percentage (about 6 per cent.) for the hospital population. It is quite likely that, since before 1938 many cases of german measles in the general population would not have been brought to medical attention, and since the disease is notorious for the frequency with which it is misdiagnosed, the hospital histories considerably underestimate the frequency of attack. On the other hand, in the schools observed by the School Epidemics Committee, quite heavy outbreaks of german measles took 
place and it may well be that the number of susceptibles was underestimated; furthermore (as with chicken-pox), the School Epidemics Committee data were selective, many children having already attended residential preparatory schools.

Careful questioning by school doctors in a random sample of 153 5-year-old infants entering school in London A.C. in 1951 revealed histories of german measles in 7.2 per cent.; and in a sample of 151 11-year-old children, 13.2 per cent. gave a history of attack.

Clearly the disease is under-reported from schools. It seems from other evidence that perhaps one-sixth of children may expect to be attacked before the age of 10. There is a suggestion that boys are attacked relatively more frequently than girls, the ratio being about 4:3.

In London A.C. no deaths have been assigned to german measles for 17 years; there were four deaths in 1933 (three under the age of five), and one in 1934; but none has been recorded in any subsequent year.

MEASLES.-The disease has been notifiable in London A.C. since October, 1938. Before that time school reports were available, but detailed examination (Breen and Benjamin, 1949) indicated that only a small proportion of frank cases (perhaps little more than one third of those which would have been notifiable if the disease had been subject to notification and if the present level of medical attention were available) was reported from schools. The histories of hospital patients in 1938 indicated that 72 per cent. were attacked by the age of 10 , after which age attacks were rare.

On a 'notifiable' basis it has previously been estimated by Breen and Benjamin (1949) that in 1931-38 the average annual number of cases in London was 46,500 , with an annual rate of $5 \cdot 2$ per cent. in persons under the age of 15 . Such a rate would indicate that $15 \times 5 \cdot 2$ (78 per cent.) were attacked by the age of 15 , a little higher than the incidence suggested by hospital histories. The calculations of Stocks and Karn (1927) in St. Pancras indicated that 70 per cent. of the population had had measles before the age of 10 . The School Epidemics Committee found attack rates of $72 \cdot 5$ per cent for boys and 63.1 per cent. for girls entering public boarding-schools.

Before the war of 1939-45 there had been a regular biennial periodicity in the occurrence of measles epidemics. Every two years incidence rose sharply in October or November, reached a maximum in March or April, and thereafter fell by June or July to a low interepidemic level. Thus, apart from a slight increase of prevalence at the end of the following winter, incidence was low for an intervening period between epidemics of some 16 or 17 months. On the outbreak of war in 1939 evacuation movements disturbed the normal rhythm and the biennial epidemics were replaced by less extensive outbreaks. An epidemic rise in notifications occurred at the beginning of every year (sometimes in the preceding December) from 1941 to 1949 . The average annual number of notifications in 1946-49 (to select a period of more stable population) was 24,939, with an annual attack rate of 3.86 per cent. under the age of 15 . This rate is consistent with notification of 58 per cent. of children before the age of 15 (55 per cent. when age specific rates are taken into account). The corresponding figure at the 1931-38 rate is over 70 per cent.

Since 1949 there have been signs of further change. Recent notification figures for London A.C. are given in Table IX.

TABLE IX

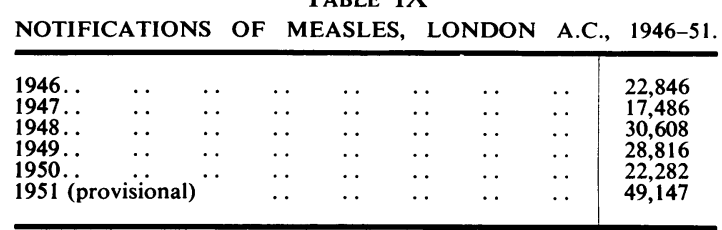

The winter incidence of 1949-1950 (expected on the basis of the post-1940 annual rhythm) was very late. Notifications were at a minimal level throughout January to March (60 per week) and began to rise steadily in April, reaching 600 per week in June. This level was maintained with only minor fluctuations (a flat tableland in the epidemic curve) until the normal refractory period of August and September, when notifications fell to 150 a week by midSeptember. Almost immediately, however, a rapid rise in notification took place to 500 a week at the beginning of November, 1,900 at the end of the year, over 2,200 a week in January, 1951, and a peak of 3,750 in the third week of February (twice as high as the highest peak in any year since 1940). Thereafter notifications gradually declined to 2,000 in the first week of April, and 870 in the first week of May. Whether or not this irregularity signifies the resumption of biennial periodicity cannot yet be determined. The 1950-51 pattern for London is more in keeping with observations, eslsewhere in England and Wales.

For the post-war years, 1946-51, we obtain the mean annual age-sex specific notification rates (1951 figures are provisional) given in Table X.

These rates are consistent with notifications of 63.5 per cent. for boys and 63.9 per cent. for girls before the age of 15 . There is a slight female excess 
TABLE $X$

MEAN ANNUAL MEASLES NOTIFICATION RATES PER CENT., BY SEX, LONDON A.C., 1946-51.

\begin{tabular}{c|c|c|c}
\hline \multicolumn{1}{c|}{ Age } & Male & Female & Total \\
\hline $0-1$ & $2 \cdot 04$ & $2 \cdot 12$ & $2 \cdot 08$ \\
$1-2$ & $6 \cdot 66$ & $6 \cdot 50$ & $6 \cdot 58$ \\
$3-4$ & $10 \cdot 14$ & 9.99 & $10 \cdot 06$ \\
$5-9$ & $5 \cdot 34$ & $5 \cdot 46$ & 5.40 \\
$10-14$ & $0 \cdot 23$ & $0 \cdot 29$ & 0.26 \\
15 and over & 0.02 & 0.03 & 0.02 \\
\hline Total & 0.94 & 0.79 & 0.86 \\
\hline
\end{tabular}

in the first year of life, a small male excess in the next 4 years, and a female excess again at the older ages. In the national figures (Stocks, 1949), the female excess is well marked in the first year of life and again after the age of 10, but between the ages of 1 and 10 there is little difference in the rates for the two sexes. The fact that the 'all ages' rate is so much higher for males than for females is due to the excessive weight given to adults in the female age distribution.

The most striking feature of measles experience has been the fall in mortality. The decline of deaths (per cent. of notified cases) in London A.C. is shown in Table XI.

TABLE XI

MEASLES FATALITY RATES, LONDON A.C., 1921-50.

\begin{tabular}{c|c}
\hline Period or Year & Deaths per 100 Cases \\
\hline $1921-25$ & 1.43 \\
$1926-30$ & 1.21 \\
$1931-35$ & 0.92 \\
$1936-40$ & 0.51 \\
$1941-45$ & 0.20 \\
1946 & 0.09 \\
1947 & 0.13 \\
1948 & 0.085 \\
1949 & 0.056 \\
1950 & 0.018 (4 deaths) \\
\hline
\end{tabular}

Mumps.-Mumps is not notifiable in London A.C. School reports of the pre-war and post-war incidence are shown in Table XII.

TABLE XII

L.C.C. SCHOOL ABSENCES FROM MUMPS, 1931-1950.

\begin{tabular}{c|c|c}
\hline $\begin{array}{c}\text { Period } \\
\text { or } \\
\text { Year }\end{array}$ & $\begin{array}{c}\text { Average Annual Number } \\
\text { of Cases }\end{array}$ & $\begin{array}{c}\text { Average Annual Attack } \\
\text { Rate per cent. of } \\
\text { School Rool }\end{array}$ \\
\hline $1931-35$ & 8,369 & $1 \cdot 50$ \\
$1936-38$ & 7,146 & $1 \cdot 54$ \\
$1946-50$ & 5,410 & $1 \cdot 48$ \\
1946 & 5,296 & $1 \cdot 58$ \\
1947 & 2,845 & $0 \cdot 81$ \\
1948 & 9,162 & $2 \cdot 46$ \\
1949 & 2,113 & $0 \cdot 56$ \\
1950 & 7,638 & $2 \cdot 01$ \\
\hline
\end{tabular}

Since 1931 the incidence of mumps seems to have been relatively stable when expressed as an average annual rate, but this average conceals considerable variation from year to year, as is demonstrated by the cases reported in individual years 1946-50.

There is no constant rhythm, though quite often years of high incidence seem to alternate with years of low incidence. Incidence is maximal in the late autumn and minimal in the late winter (February), and there is also a recession for a few weeks after the summer closing of schools. There is no sharp outbreak at any particular point of the year. The lowest weekly number of cases in 1950 was 34 and the highest 415 .

The 1938 hospital data indicated that the experience of boys and girls was similar up to the age of 7 , but that beyond that age incidence was higher in boys than in girls. Some 10 per cent. of children of both sexes are attacked before the age of 7 , but some 20 per cent. of boys aged 15 have been attacked as compared with only 11 per cent. of girls. The L.C.C. school reports indicate that 15 per cent. of all children are attacked between the ages of 5 and 15. This is a higher estimate than the 9 per cent. which is obtained by taking both sexes together in the hospital data. The School Epidemics Committee (1938) found that, of entrants to public boardingschools, 32.5 per cent. of boys and 21.9 per cent. of girls had a history of mumps. These percentages are, for reasons already stated, probably higher than those applicable to day-school children in general, but they show the same kind of excess for boys as that exhibited in the hospital data.

Logan (1951), and the basis of Social Survey data, estimates that "perhaps a quarter of boys and a third of girls will have had mumps by the age of 15". This information, elicited by non-medical interviewers, shows a sex difference the reverse of that indicated by the School Epidemics Committee data, and L.C.C. hospital histories show much higher rates for girls than those found by the School Epidemics Committee. Logan (1951) also quotes a personal communication from Bransby, who found from school absence data that 45 per cent. of children are attacked before the age of 12 . Clearly there is a wide range of estimates from which to choose.

Death is very rarely attributed to mumps. Since 1931 in London there have been seven deaths under the age of 15 , and six over that age. Five of those under the age of 15 occurred in the triennium 1934-36.

WhoOPING Cough.-Precise details of the pre-war incidence of whooping cough are not available, as the disease was not made notifiable until 1938. Notification rates for London A.C. by sex and age 
groups for the years 1946-50 are shown in Table XIII.

TABLE XIII

NOTIFICATIONS OF WHOOPING COUGH, BY SEX, LONDON A.C., $1946-50$.

\begin{tabular}{l|c|c|c|c}
\hline \multirow{2}{*}{ Age } & \multicolumn{2}{|c|}{ Male } & \multicolumn{2}{|c}{ Female } \\
\cline { 2 - 5 } & $\begin{array}{c}\text { Mean } \\
\text { Annual } \\
\text { Notifi- } \\
\text { cations }\end{array}$ & $\begin{array}{c}\text { Per cent. } \\
\text { of } \\
\text { Population }\end{array}$ & $\begin{array}{c}\text { Mean } \\
\text { Annual } \\
\text { Notifi- } \\
\text { cations }\end{array}$ & $\begin{array}{c}\text { Per cent. } \\
\text { of } \\
\text { Population } \\
\text { Pond }\end{array}$ \\
\hline $0-1$ & 553 & 1.65 & 531 & 1.67 \\
$1-2$ & 1,226 & 1.99 & 1,324 & 2.27 \\
$3-4$ & 1,117 & 2.57 & 1,301 & 3.14 \\
$5-9$ & 1,098 & 1.17 & 1,309 & 1.44 \\
$10-14$ & 39 & 0.04 & 49 & 0.06 \\
15 and over & 20 & 0.002 & 66 & 0.004 \\
\hline
\end{tabular}

These figures indicate that the disease is primarily one of infancy and pre-school life, and that its incidence is negligible after the age of 9 ; more detailed figures show that a rapid decline in incidence begins at the age of 5 . From the age of one year, incidence is higher in girls than in boys. L.C.C. school figures of reported cases of whooping cough originated in 1913. The mean annual cases per cent. of the school population in quinquennia since 1921 are shown in Table XIV.

TABLE XIV

L.C.C. SCHOOL ABSENCES FROM WHOOPING COUGH,

\begin{tabular}{c|c}
\multicolumn{2}{c}{$1921-50}$. \\
\hline Period & Cases per cent. of School Roll \\
\cline { 2 - 2 } $1921-25$ & $1 \cdot 43$ \\
$1926-30$ & $1 \cdot 17$ \\
$1931-35$ & 1.35 \\
$1936-40$ & 1.27 \\
$1941-45$ & 0.96 \\
$1946-50$ & 0.86 \\
\hline
\end{tabular}

That there is a certain amount of under-notification is suggested by a comparison of the school figures with the notification rates for the ages of 5 to 14 years. The actual numbers of notifications and reported cases from schools for the period 1946-50 were: Notifications, 12,473; Cases reported from schools, 15,625 . Under-notification is probably even greater than these figures suggest, since the school figures exclude holidays.

Hospital histories are given in Table XV. These figures do not agree with the notification rates. They relate to different periods, but, even allowing for a decline of 30 per cent. in incidence (based on school mean annual rates of 1.27 per cent. in 1936-40 and 0.86 per cent. in 1946-50) since 1938 , the notification figures are still too low. On the other hand, if the school mean annual attack rate of 1.27 per cent. for the late 1930s be accepted as comparable with the 1938 hospital histories (which give an attack rate during ten years of school life of $12 \cdot 7$ per cent.), then this is fairly consistent with the increase in the
TABLE XV

INCIDENCE OF WHOOPING COUGH IN HOSPITAL ADMISSIONS, BY SEX, 1938.

\begin{tabular}{|c|c|c|c|c|c|c|c|c|}
\hline \multirow{3}{*}{ Age } & \multicolumn{4}{|c|}{ Male } & \multicolumn{4}{|c|}{ Female } \\
\hline & \multirow{2}{*}{$\begin{array}{l}\text { Total } \\
\text { Hos- } \\
\text { pital } \\
\text { Ad- } \\
\text { mis- } \\
\text { sions }\end{array}$} & \multicolumn{3}{|c|}{$\begin{array}{l}\text { Patients with History } \\
\text { of Whooping Cough }\end{array}$} & \multirow{2}{*}{$\begin{array}{c}\text { Total } \\
\text { Hos- } \\
\text { pital } \\
\text { Ad- } \\
\text { mis- } \\
\text { sions }\end{array}$} & \multicolumn{3}{|c|}{$\begin{array}{l}\text { Patients with History } \\
\text { of Whooping Cough }\end{array}$} \\
\hline & & No. & $\begin{array}{l}\text { Per } \\
\text { cent. }\end{array}$ & \begin{tabular}{|c|} 
Gradu- \\
ated per- \\
centage
\end{tabular} & & No. & $\begin{array}{l}\text { Per } \\
\text { cent. }\end{array}$ & $\begin{array}{l}\text { Gradu- } \\
\text { ated per- } \\
\text { centage }\end{array}$ \\
\hline $\begin{array}{l}0- \\
1- \\
2- \\
3- \\
4- \\
5- \\
6- \\
7- \\
8- \\
9- \\
10-14 \\
15\end{array}$ & $\begin{array}{r}378 \\
416 \\
411 \\
276 \\
221 \\
172 \\
163 \\
116 \\
87 \\
71 \\
186\end{array}$ & $\begin{array}{r}8 \\
31 \\
59 \\
55 \\
60 \\
46 \\
58 \\
45 \\
30 \\
23 \\
59\end{array}$ & $\begin{array}{r}2 \cdot 1 \\
7.5 \\
14 \cdot 4 \\
19.9 \\
27 \cdot 1 \\
26 \cdot 7 \\
35 \cdot 6 \\
38 \cdot 8 \\
34 \cdot 5 \\
32.4 \\
31 \cdot 7\end{array}$ & $\begin{array}{r}0 \cdot 5 \\
4 \cdot 0 \\
10 \cdot 0 \\
16.9 \\
23 \cdot 1 \\
27 \cdot 8 \\
30.9 \\
32 \cdot 7 \\
33 \cdot 5 \\
33.9 \\
34 \cdot 1 \\
34 \cdot 1\end{array}$ & $\begin{array}{r}317 \\
362 \\
422 \\
258 \\
186 \\
205 \\
138 \\
96 \\
63 \\
64 \\
142\end{array}$ & $\begin{array}{l}4 \\
36 \\
53 \\
57 \\
67 \\
63 \\
60 \\
30 \\
25 \\
24 \\
58\end{array}$ & $\begin{array}{r}1 \cdot 3 \\
9.9 \\
12.6 \\
22.1 \\
36 \cdot 0 \\
30 \cdot 7 \\
43 \cdot 5 \\
31 \cdot 3 \\
39 \cdot 7 \\
37.5 \\
40.8\end{array}$ & $\begin{array}{r}0 \cdot 7 \\
5 \cdot 8 \\
13 \cdot 4 \\
22 \cdot 7 \\
29 \cdot 8 \\
34 \cdot 4 \\
37 \cdot 0 \\
38 \cdot 2 \\
38 \cdot 7 \\
38 \cdot 9 \\
38 \cdot 9 \\
38 \cdot 9\end{array}$ \\
\hline
\end{tabular}

graduated percentages between the ages of 5 and 15 of the hospital histories. Such agreement suggests that the figure of annual cases reported from schools is a fairly satisfactory index of the level of incidence in schoolchildren. On this assumption it is fair to scale down the 1938 hospital history figures by 30 per cent. to bring them into line with the present level of incidence and so give an estimate of the probable attack rate from whooping cough. This is done in Table XVI, where the 1938 figures are compared with the 1946-50 notification figures.

TABLE XVI

1938 HOSPITAL HISTORY GRADUATED PERCENTAGES SCALED DOWN BY 30 PER CENT. AND EXPECTED HISTORY BASED ON NOTIFICATION FIGURES FOR 1946-50, BY SEX.

\begin{tabular}{|c|c|c|c|c|}
\hline \multirow[b]{2}{*}{ Age } & \multicolumn{2}{|c|}{ Male } & \multicolumn{2}{|c|}{ Female } \\
\hline & 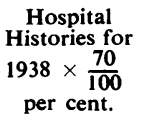 & \begin{tabular}{|c|} 
Expected from \\
$1946-50$ \\
Notifications \\
per cent.
\end{tabular} & $\begin{array}{l}\text { Hospital } \\
\text { Histories for } \\
1938 \times \frac{70}{100} \\
\text { per cent. }\end{array}$ & $\begin{array}{c}\text { Expected from } \\
1946-50 \\
\text { Notifications } \\
\text { per cent. }\end{array}$ \\
\hline $\begin{array}{l}0- \\
1- \\
2- \\
3- \\
4- \\
5- \\
6- \\
7- \\
8- \\
9- \\
10-14 \\
15\end{array}$ & $\begin{array}{r}0.4 \\
2.8 \\
7.0 \\
11.8 \\
16.2 \\
19.5 \\
21.6 \\
22.9 \\
23.5 \\
23.7 \\
23.9 \\
23.9\end{array}$ & $\begin{array}{r}1 \cdot 7 \\
5 \cdot 6 \\
10 \cdot 8\end{array}$ & $\begin{array}{r}0 \cdot 5 \\
4.0 \\
9.4 \\
15 \cdot 9 \\
20.9 \\
24 \cdot 1 \\
25 \cdot 9 \\
26 \cdot 7 \\
27 \cdot 1 \\
27 \cdot 2 \\
27 \cdot 2 \\
27 \cdot 2\end{array}$ & $\begin{array}{r}1 \cdot 7 \\
6 \cdot 2 \\
12 \cdot 5\end{array}$ \\
\hline
\end{tabular}

These estimates however still appear to be too low. Stocks (1949) has suggested that between one-quarter and one-fifth of children with whooping cough are notified. This suggestion is based on a comparison of local surveys dated about 1930 (which indicated that about 60 per cent. were attacked by the age of 10) with the 1944-47 national notification data estimate (13-15 per cent. by the age of 15). It was assumed that incidence had not substantially 
declined. However our school data show a decline in incidence between 1920-30 and 1950 of about 40 per cent., and the local survey figures referred to by Stocks should be reduced by that amount to give an estimate of only 35 per cent. attacked by the age of 10. Under-notification is therefore perhaps not so extensive as Stocks was led to suggest; probably over one-half of all cases are notified. Nevertheless the adjusted estimates based on hospital data are clearly too low. It appears likely that 25 per cent. of children are attacked by the age of 5 , and 35 per cent. by the age of 15 .

The School Epidemics Committee (1938) gives proportions of 70 per cent. for boys and 67 per cent. for girls as having had an attack of whooping cough before entry to public boarding-schools. These rates are apparently excessive, and confirm, as has been remarked earlier, that the children attending public schools are drawn from a select population.

It is often suggested that whooping cough shows both seasonal and epidemic periodicity, but this does not allow of any simple treatment.

Mortality from whooping cough has, like measles, shown a sharp decline in the past 20 years (Table XVII).

\section{TABLE XVII}

LONDON A.C. MORTALITY FROM WHOOPING COUGH PER 1,000 OF POPULATION, BY SEX, 1931-48.

\begin{tabular}{|c|c|c|c|c|}
\hline \multirow{3}{*}{ Period } & \multicolumn{4}{|c|}{ Mean Annual Rates } \\
\hline & \multicolumn{2}{|c|}{ Male } & \multicolumn{2}{|c|}{ Female } \\
\hline & $\begin{array}{l}\text { Under } \\
1 \text { year }\end{array}$ & $\begin{array}{c}1-4 \\
\text { years }\end{array}$ & $\begin{array}{l}\text { Under } \\
1 \text { year }\end{array}$ & $\begin{array}{c}1-4 \\
\text { years }\end{array}$ \\
\hline $\begin{array}{l}1931-33 \\
1936-38 \\
1946-48\end{array}$ & $\begin{array}{l}2 \cdot 24 \\
2 \cdot 02 \\
0 \cdot 63\end{array}$ & $\begin{array}{l}0.64 \\
0.36 \\
0.09\end{array}$ & $\begin{array}{l}2 \cdot 51 \\
2 \cdot 27 \\
0 \cdot 60\end{array}$ & $\begin{array}{l}0 \cdot 81 \\
0.49 \\
0 \cdot 10\end{array}$ \\
\hline
\end{tabular}

The well-known sex difference in mortality is exhibited for the period 1931-38, but not for 1946-48. Case-mortality ratios are not calculated owing to the absence of data on pre-war incidence. The decline in mortality has been much greater than the decline in incidence.

SCARLET FeVER.- The annual incidence of notified cases of scarlet fever in London A.C. is shown in Table XVIII.

TABLE XVIII

NOTIFICATIONS OF SCARLET FEVER PER 1,000 POPULATION (ALL AGES), LONDON A.C., 1931-50.

\begin{tabular}{|c|c|c|c|c|c|c|c|}
\hline Year & $\%$ & Year & $\%$ & Year & $\%$ & Year & $\%$ \\
\hline $\begin{array}{l}1931 \\
1932 \\
1933 \\
1934 \\
1935\end{array}$ & $\begin{array}{l}2 \cdot 73 \\
3 \cdot 26 \\
5 \cdot 11 \\
4 \cdot 32 \\
2 \cdot 63\end{array}$ & $\begin{array}{l}1936 \\
1937 \\
1938 \\
1939 \\
1940\end{array}$ & $\begin{array}{l}2 \cdot 55 \\
2.07 \\
2.00 \\
1 \cdot 51 \\
0.81\end{array}$ & $\begin{array}{l}1941 \\
1942 \\
1943 \\
1944 \\
1945\end{array}$ & $\begin{array}{l}1.00 \\
1.84 \\
3.80 \\
1.57 \\
1.57\end{array}$ & $\begin{array}{l}1946 \\
1947 \\
1948 \\
1949 \\
1950\end{array}$ & $\begin{array}{l}1.42 \\
1.31 \\
1.37 \\
1.46 \\
1.23\end{array}$ \\
\hline
\end{tabular}

Goodall and Washbourn (1908) say that:

The second quinquennial period of life furnishes the largest number of cases . . . the fourth is the year of highest susceptibility. Children under a year old are not very prone to take scarlet fever.

That these general observations held good in more recent times is borne out by the histories of hospital patients in 1938, which indicated that 1 per cent. were attacked by the age of $2 ; 7$ per cent. by the age of 5 ; and 20 per cent. by the age of 10 , with only a gradual increase beyond this age.

The rates in Table XIX for 1936-38 are much lower than would be suggested by hospital histories. It may be that parents recall illnesses suggestive of scarlet fever although the illnesses were not notified. Stocks (1949) considered notification to be complete, and deduced that 10 per cent. of children suffer a notifiable attack before the age of 15 . L.C.C. report figures are given in Table XX.

TABLE XIX

SCARLET FEVER NOTIFICATION RATES, LONDON A.C., BY SEX, 1936-38 AND 1946-50.

\begin{tabular}{|c|c|c|c|c|c|}
\hline \multirow[b]{2}{*}{ Period } & \multirow[b]{2}{*}{ Age } & \multicolumn{2}{|c|}{ Male } & \multicolumn{2}{|c|}{ Female } \\
\hline & & $\begin{array}{c}\text { Mean } \\
\text { Annual } \\
\text { Cases }\end{array}$ & $\begin{array}{c}\text { Per cent. } \\
\text { of } \\
\text { Population }\end{array}$ & $\begin{array}{c}\text { Mean } \\
\text { Annual } \\
\text { Cases }\end{array}$ & $\begin{array}{c}\text { Per cent. } \\
\text { of } \\
\text { Population }\end{array}$ \\
\hline \multirow[t]{2}{*}{$1936-38$} & \multirow{2}{*}{$\begin{array}{c}0- \\
1- \\
3- \\
5- \\
10- \\
15 \text { and } \\
\text { over }\end{array}$} & $\begin{array}{r}39 \\
527 \\
851 \\
1,640 \\
579\end{array}$ & $\begin{array}{l}0 \cdot 14 \\
1 \cdot 04 \\
1 \cdot 78 \\
1 \cdot 16 \\
0 \cdot 42\end{array}$ & $\begin{array}{r}37 \\
482 \\
823 \\
1,911 \\
694\end{array}$ & $\begin{array}{l}0 \cdot 14 \\
0 \cdot 97 \\
1 \cdot 73 \\
1 \cdot 38 \\
0 \cdot 51\end{array}$ \\
\hline & & 576 & $0 \cdot 04$ & 927 & 0.05 \\
\hline \multirow[t]{2}{*}{$1946-50$} & \multirow{2}{*}{\begin{tabular}{|c|}
$0-$ \\
$1-$ \\
$3-$ \\
$5-$ \\
$10-$ \\
15 and \\
over
\end{tabular}} & $\begin{array}{r}13 \\
256 \\
474 \\
1,020 \\
271\end{array}$ & $\begin{array}{l}0 \cdot 04 \\
0 \cdot 42 \\
1 \cdot 09 \\
1 \cdot 09 \\
0 \cdot 31\end{array}$ & $\begin{array}{r}10 \\
190 \\
435 \\
1,129 \\
375\end{array}$ & $\begin{array}{l}0 \cdot 03 \\
0 \cdot 33 \\
1 \cdot 05 \\
1 \cdot 24 \\
0 \cdot 44\end{array}$ \\
\hline & & 134 & $0 \cdot 01$ & 214 & $0 \cdot 01$ \\
\hline
\end{tabular}

TABLE XX

L.C.C. SCHOOL ABSENCES FROM SCARLET FEVER, 1936-38 AND 1946-50.

\begin{tabular}{c|c|c}
\hline Period & Mean Annual Cases & $\begin{array}{c}\text { Annual Attack Rate } \\
\text { per cent. of School Roll }\end{array}$ \\
\cline { 2 - 3 } $1936-38$ & 4,246 & $\begin{array}{l}0 \cdot 92 \\
0 \cdot 55\end{array}$ \\
\hline $1946-50$ & 1,998 & \\
\hline
\end{tabular}

Allowing for a 10-year school life with a total attack rate of $10 \times 0.92(9.2)$, the school figure for 1936-38 is lower than that indicated by hospital histories for the ages of 5 to 15 years in 1938. It may be that the hospital histories overstate the incidence. The position today would appear to be that 4-5 per cent. of children are attacked by the age of 5 , and 10-12 per cent. by the age of 15 .

The School Epidemics Committee (1938) found that, of boys and girls entering public boarding-schools, 
$8 \cdot 3$ per cent. of boys and $7 \cdot 1$ per cent. of girls had a history of scarlet fever.

The incidence of scarlet fever is higher in males than in females up to the age of 3 , after which it is higher in females. The disease now rarely causes death; in 1950 there were only four deaths from scarlet fever or streptococcal sore throat in London A.C. There is a seasonal swing which varies in degree from year to year; there is some diminution in incidence in August and September and often a heavier than average incidence in the late autumn and early winter months.

\section{SUMMARY}

(1) The incidence of common infections of childhood, as variously indicated by school reports, hospital histories, and statutory notifications, are reviewed in order to give a measure of the risk of infection during pre-school and school life. Statistical deficiencies are discussed.

(2) The estimated proportions (per cent.) of children at the ages of 5 and 15 years who will have previously experienced an attack of each disease studied are as follows:

\begin{tabular}{|c|c|c|c|c|}
\hline \multirow{2}{*}{\multicolumn{3}{|c|}{ Disease }} & \multicolumn{2}{|c|}{ Percentage of Children Attacked } \\
\hline & & & By the age of 5 yrs & By the age of $15 \mathrm{yrs}$ \\
\hline $\begin{array}{l}\text { Chicken-pox.. } \\
\text { Rubella } \quad . . \\
\text { Measles .. } \\
\text { Mumps .. } \\
\text { Whooping cough } \\
\text { Scarlet fever .. } \\
\text { Diphtheria .. }\end{array}$ & $\begin{array}{l}\cdots \\
\cdots \\
\cdots \\
\cdots \\
\cdots\end{array}$ & $\begin{array}{l}\cdots \\
\cdots \\
\cdots \\
\cdots \\
\cdots\end{array}$ & $\begin{array}{c}20 \\
7 \\
35 \\
10 \\
25 \\
4-5 \\
\text { The incidence is }\end{array}$ & \begin{tabular}{|c}
45 \\
15 \\
65 \\
$15-30$ \\
35 \\
$10-12$ \\
now so sporadic \\
eliable estimate.
\end{tabular} \\
\hline
\end{tabular}

We are grateful to Sir Allen Daley, lately County Medical Officer of Health, for encouragement in the preparation of this paper; to Dr. G. E. Breen, formerly epidemiologist in the Department, who first suggested that this study should be made; to Dr. Ian Taylor, epidemiologist, for criticism; and to Mr. C. A. Gould for valuable help in the calculations.

\section{REFERENCES}

Breen, G. E., and Benjamin, B. (1949). Lancet, 2, 620.

Goodall, E. W., and Washbourn, J. W. (1908). "A Manual of Infectious Diseases", 2nd ed. Lewis, London.

Logan, W. P. D. (1951). Monthly Bull. Minist. Hlth, Lond., 10, 136. London County Council, Annual Report. (1937.) Vol. 4. Part I,

p. 100 .
Medical Research Council, School Epidemics Committee (1938). "Epidemics in Schools." Spec. Rep. Ser. med. Res. Coun., No. 227. H.M.S.O., London.

Stocks, P. (1949.) "Sickness in the Population of England and Wales in 1944-1947". Studies on Medical and Population Subjects,

No. 2. H.M.S.O., London.

- and Karn, M. N. (1927). Ann. Eugen., Camb., 2, 395. 